\title{
FROM VLADIMIRI'S JUST WAR TO KELSEN'S LAWFUL WAR: THE UNIVERSALITY OF THE BELLUM JUSTUM DOCTRINE
}

\begin{abstract}
The article explores Hans Kelsen's theory of just war (bellum justum). It addresses the question of how and why the leading modern positivist thinker in fact embraced a key natural law theory, the concept of just war. In exploring this question, it collates the Viennese philosopher's views with those of Polish late Middle Ages philosopher and lawyer, Paulus Vladimiri, who developed his own version of the bellum justum doctrine. In the first step, an outline of Paulus Vladimiri's views on just war is presented. Secondly, the article offers an overview of two key theses of Kelsen's theory of international law in order to provide the necessary context for his use of the term bellum justum. Next, the analysis moves to answering the question of whether Kelsen's position might in fact be described as naturalist. In the last part, the article adds to some criticism of Kelsen's use of the term "just war". The conclusion underlines the points of intersection between the two doctrines. Although Kelsen's attempt to harness the just war tradition within the confines of his own pure theory of law seems to have largely failed, it exemplifies a degree of universalism of the just war tradition and its potential for transcending divisions among schools of legal and philosophical thinking.
\end{abstract}

Keywords: just war, bellum justum, Paulus Vladimiri, Hans Kelsen, pure theory of law, international law

1. Introduction. 2. Paulus Vladimiri's just war theory. 3. Kelsen's assumptions on international law. 4. The role of the bellum justum doctrine in Kelsen's theory. 5. Is Kelsen a naturalist? 6. Relevance of Kelsen's concept of lawful war. 7. Conclusion.

\section{INTRODUCTION}

This article highlights the universality of the just war theory as a source of theoretical inspiration for otherwise drastically divergent ways of legal and philosophical thinking. It has influenced the work of many of the great legal-philosophical minds of their times. One of them was Professor Hans Kelsen, often described as "the best 


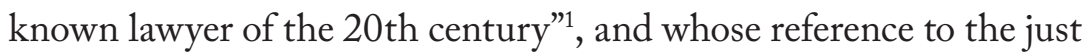
war theory will be the main subject of this analysis. Another was the forerunner of Polish philosophy of law and the law of nations Paulus Vladimiri, appraised on this occasion of the 600-years jubilee of his Corpus Diplomaticum, which was presented to the Council of Constance in 1415. Vladimiri's work on the just war theory will serve as an exemplification of a classic medieval bellum justum doctrine and as a reference against which the Kelsenian use of the notion will be analysed. On the face of it, the collation of these two may seem rather odd - the two men are not only separated by five centuries in time and ages of developments in legal philosophy, but also represent two opposing schools of legal thought. While Paulus Vladimiri is closely related to the scholastic legal naturalism of St. Thomas Aquinas, Kelsen surely remains one of the pivotal figures of 20th century legal positivism. Surprisingly though, the author of the modern extreme positivist "pure" approach in the science of law took a strong stance against the classical idea of the sovereignty of nation states and in favour of the undisputed primacy of international law. This led Kelsen to include in his theory the notion of just war. In 1934, he wrote: "[A] nyone who rejects the theory of the just war denies, indeed, the legal nature of international law" 2 . This article addresses the question of how and why the leading modern positivist thinker in fact embraced a key natural law theory concept of just war. In the first step, an outline of Paulus Vladimiri's views on the just war question will be presented. Secondly, an overview of two key theses of Kelsen's theory of international law will be given in order to provide the necessary context for his use of the term bellum justum. Next, the analysis will move to answering the question of whether Kelsen's position might

1 A. Bosiacki, Wstęp, in: H. Kelsen, Czysta teoria prawa, ed. A. Bosiacki, trans. R. Szubert, Warszawa 2014, 7.

2 H. Kelsen, The Legal Process and International Order, London 1934, 10. 
in fact be described as naturalist. In the last part, I will add to some criticism of Kelsen's use of the term "just war".

\section{PAULUS VLADIMIRI'S JUST WAR THEORY}

In the course of discussion on the rich heritage of medieval philosophy relating to the just war theory, Polish historical achievements in this field are too rarely mentioned. ${ }^{3}$ Probably the most outstanding representative of the early Polish school of the law of nations is Paulus Vladimiri, known also by his original name, Paweł Włodkowic (ca. 1370-1436). Vladimiri held a doctorate in law and a master's degree in liberal arts. He was a professor and Rector of the renewed Jagiellonian Academy of Kraków, and a graduate from the Universities of Prague and Padua. A true man of the Renaissance and clearly ahead of his time, he demonstrated outstanding skills in diplomacy, politics and philosophy. Paulus Vladimiri is most famously known for acting as the spokesman for the Polish King in his dispute with the Teutonic Knights. The series of powerful legal-philosophical opinions presented by Vladimiri on behalf of the King of Poland before the Ecumenical Council of Constance in the years 1414-1418 during a lawsuit against the policies and actions of the Teutonic Knights in the territories of the Baltic states remains his most frequently mentioned achievement. ${ }^{4}$ Apart from that, Vladimiri led the life of a true European of his age. For many of the early and later years of his life, he travelled through Europe, studying, giving lectures and actively participating in the practice of contemporary international relations as the royal envoy to the Pope of Rome, advisor of the Polish delegation in the arbitration proceedings in Buda in 1412, as well as a member of the delegation and a representative of the Polish King during

3 For one of the exceptions on the part of textbooks, see: D. Armstrong, T. Farell, H. Lambert, International Law and International Relations, New York 2007, 48-49.

4 Cf. R. Bierzanek, J. Symonides, Prawo międzynarodowe publiczne, Warszawa 2003, 43. 
the conclusion of the act of the Polish-Lithuanian union in Horodło (1413). Later, He stayed in Rome as the ambassador of the Polish King until the end of 1426, where he participated in the proceedings of the beatification of the Polish Queen St. Jadwiga. He also served as the canon and prebendary of the Church of Poznan. ${ }^{5}$

The Key to understanding Vladimiri's doctrine of just war and his wider view of the law of nations was his deep humanism and grounding in the fundamental assumption of the dignity of the individual human person. As aptly noted by T. Jasudowicz: "[T] he accent put on the human being and her nature is so strong in Vladimiri's writings that somehow it determines his view of the law and the legal order and its essence with particular regard to the law of nature constituting a necessary consequence of human nature and its protection at the same time." It is worthwhile to highlight the true universalism of Vladimiri's views on the equality of all people in their fundamental rights to life, property, and their own beliefs and convictions - and in a literal sense. In contrast to the prevailing views of his time, he believed that all the people, including heretics and pagans, are entitled to these rights and freedoms, because according to him, the principle of Christian charity is not limited by faith. ${ }^{7}$ Hence, extremely consistently and systematically throughout his life, Paulus Vladimiri, both on the legal and theological plains, battled all the arguments aimed at justifying the Teutonic wars of aggression against "the enemies of the Cross of Christ." If it is not permissible to remove Jews or non-believers from the protection of the law or to persecute them in a Christian state, according to Vladimiri, they are even more entitled to their own lands and countries, because "it is not allowed to deny

5 T. Jasudowicz, Śladami Ludwika Ehrlicha: do Pawła Włodkowica po naukę o prawach człowieka, Toruń 1995, I-III.

6 Ibidem, 19-20.

7 E.A. Wesołowska, Paweł Włodkowic - współczesne znaczenie poglądów i dokonań, Płock 2001, 28. 
them that which is granted by the law of human society." ${ }^{8}$ The consequences of these assumptions are far-reaching, putting to the fore in the views of the scholar from Kraków the principles of equality and non-discrimination, as well as tolerance. ${ }^{9}$ They are valid not only in the individual and nation-wide relations within a Christian state, but also within the entire civitas maxima or the cosmopolitan world society of all people.

Putting forward the argument that the gentiles and the neophytes are entitled to their countries (lands) to the same extent as Christians, because "originally all was common, and later things began to belong to the one who took them in possession" was obviously intended to consolidate the legality of the Polish-Lithuanian coalition ${ }^{10}$, but it was also absolutely consistent and deeply rooted in legal naturalistic thinking. It is even more interesting, however, that Paulus Vladimiri directly attacked the Teutonic Knights by putting forward a very progressive (if not revolutionary) argument that the Church and its organisations "should not possess states" because this level of concentration of power leads to lawlessness, looting and $\sin .{ }^{11}$ In other words, the tasks of the Church and the state are different, and the state should not be involved in the spread of faith. In this regard, Vladimiri may be seen as a precursor of the Enlightenment thesis of the separation of Church and the state. The result of these assumptions is the vision of the law of nations as the guardian of mutual respect between nations and of basing relations between them on voluntary treaties, which is a direct consequence of the principle of charity. However, even given these convictions, Vladimiri was by no means an inveterate idealist. He criticised the tactical or apparent attempts at a truce on the part of the Teutonic Knights as detrimental

8 T. Jasudowicz, op. cit., 38-39.

9 Ibidem, 48.

10 E.A. Wesołowska, op. cit., 30.

11 Ibidem, 31. 
to the achievement of true peace. ${ }^{12}$ As an experienced diplomat and lawyer, perfectly familiar with the realities of international relations, Vladimiri put a lot of effort into careful studies of the methods of the settlement of disputes and conflicts. Nevertheless, during his pleadings, he remained consistent and faithful to his anthropocentric and irenistic views. Therefore, while accepting the idea of peace as an intrinsic value, Paulus Vladimiri permits war that serves as an instrument to achieve peace. He writes in Quoniam Error: "War is waged to achieve peace. Be peaceful in war, so those whom you must defeat are led through your victory to the utility of peace."13 This is not, however, an unconditional thesis. On the contrary - Vladimiri firmly believes that "in case of doubt", we should presume that war is unjust and therefore the reasons for starting it must be carefully proven. ${ }^{14}$ By these statements, he comes to formulate his version of the doctrine of just war.

Like his contemporaries, Vladimiri took as his starting point the assumptions already formulated by the previous Christian philosophers, including primarily St. Thomas Aquinas. However, he was probably much closer to some of the more pacifist-oriented early fathers of the Church, such as Origen Adamantius, St. Ambrose and Lactantius. ${ }^{15}$ This affinity is visible in his firm belief in the general illegality of war and the emphasis on using this instrument only as a last resort. Secondly, Vladimiri argues for a substantial limitation of the key prerequisite for a just war - the justa causa, by ruling out

12 In his letter to Bishop Zbigniew Oleśnicki Paulus, Vladimiri wrote: "Consent of this kind is not the end but rather the strengthening of evil, yes - even the beginning of it and calling for all evil in the present, past and future; the beginning - because of the evil it causes for the future. For such a consent, allegedly existing in truth, lies that it is the true consent, as unfortunately its consequences often show." K. Górski, Z dziejów walki o pokój i sprawiedliwość międzynarodowa - ostatnie słowo Pawła Włodkowica o Zakonie Krzyżackim, Toruń 1964, 28-29.

13 Quote in: T. Jasudowicz, op. cit., 154.

14 Ibidem, 155.

15 E.A. Wesołowska, op. cit., 43. 
the so-called "holy war", waged in order to spread the true faith by "fire and sword". The inadmissibility of religious reasons for war stands even if permitted by the highest Christian authority, namely the Pope. ${ }^{16}$ Of course, this does not mean that in the case of a just war, an authorisation from the highest secular or spiritual power is unnecessary; Vladimiri argues only that such consent cannot authoritatively and formally outweigh the moral substance of the justa causa requirement. Obviously, just cause may not amount to the simple desire to acquire new lands or goods, which is not more than theft and plunder. ${ }^{17}$ Besides the two negative premises for the just cause, there is also a positive requirement of recta intentio, which exists "when one fights out of necessity to achieve peace". In other words, it is acceptable to get involved in warfare "for charity, justice and obedience, because war is not a sin in itself, but it is a sin to wage war for plunder." ${ }^{18}$ It is also permissible to fight in the war for "repossession" or "defence of the motherland." Last but not least, Vladimiri also rules out the possibility of warfare by the clergy. Moreover, he does not carry out this analysis of the elements of the theory of just war only in the abstract. A specific case study is conducted in his letter to the Bishop Zbigniew Oleśnicki, in which he discusses the requirements as applied to the case of wars waged by the Teutonic Knights against the Polish lands. ${ }^{19}$

However, the most critical and creative contribution of Vladimiri's legal mind to the doctrine of just war was noticed only in the $20^{\text {th }}$ century by legal scholars such as S. Bełch, L. Ehrlich and T. Jasudowicz. It is his emphasis on the procedural element in deciding on the justness of a possible war. As mentioned above, Vladimiri did not agree that the act of the authorisation of war is a sufficient

16 Ibidem, 44; cf. T. Jasudowicz, op. cit., 157.

17 T. Jasudowicz, op. cit., 157.

18 Quote in: Ibidem, 157-158.

19 See: List do Zbigniewa Oleśnickiego, in: K. Górski, op. cit.., par. 18-20. 
link in determining the validity of the cause. As he put it himself: "What is required is the proof of the law or of fact. Proof of the law cannot be given except by way of justice, namely by the evidence carried out either by legal demonstration or by the court judgment and, consequently, by legitimate declaration." ${ }^{20}$ Such a proof can be carried out before the relevant international authority, which administers the appropriate sanctions, which, at the time of Vladimiri, was the Council of Constance. This is true also as far as the facts are concerned, because in the case of war, facts should never be considered notorious and should always require proof. It follows that Paulus Vladimiri puts forward a formal requirement for the recognition of war as just by way of appropriate "legal proceedings", which is consistent with the aforementioned presumption of the injustice or illegality of war. To this end, he suggests taking one of the two ways: either by means of a judicial process as to the veracity of the facts (processus iudicialis) or through an adversarial process (processus doctrinalis), which is a dispute about the principles and standards that apply to the case at hand. ${ }^{21}$ In this proposal by the Rector of the Academy of Kraków, one can see not only an extremely progressive vision of the law of nations and some elements of the idea of the rule of law at the international level, but also a timely proposal that continues to be topical today. As will be discussed below, this line of thinking is surprisingly linked with the modernist "pure" science of law promoted by Hans Kelsen in the course of the 20th century.

\section{KELSEN'S ASSUMPTIONS ON INTERNATIONAL LAW}

Hans Kelsen's argument about the bellum justum principle is grounded in his general theory of international law, which rests on two

20 Quoniam Error, II, 308, in: T. Jasudowicz, op. cit., 158.

21 L. Ehrlich, Przedmowa, LV in: Pisma wybrane Pawła Włodkowica, ed. L. Ehrlich, Warszawa 1968. 
central claims: the identity thesis and the primacy thesis. They will be briefly presented below.

Identity thesis. Kelsen believed that the state and the legal system are one and the same thing, because the state cannot be conceived as a real person. State actions depend on the actions of individual people, and these acts can be attributed to the state only if there is a competence contained in the legal norm for an individual to act in the name of the state. Therefore, there can be no state before the law. Any description of sovereignty in relation to a de facto power or to any social reality beyond the law is impossible methodologically, as well as false for Kelsen. ${ }^{22}$ Sovereign legal order is the one that could not be derived any further from any higher norm or order. ${ }^{23}$ Consequently, sovereignty is simply a normative independence of a legal system. There is no possibility that the state could be sovereign towards the positive law, including international law, because the state (or its personification) in Kelsen's theory is dissolved in the law itself.

Primacy thesis. The obvious consequence of Kelsen's methodological position on sovereignty was also the monistic account of the relation between international and state law. Through this theoretical move, Hans Kelsen also solved the paradigmatic puzzle of the incompatibility of national sovereignty with subjection to international law. The well-known sovereignty paradox states that if one believes that law is a system of coercive rules that enforce behaviour on the part of its subjects in order to manage conflict between them, then international law cannot be deemed as law proper, because its sovereign subjects (the states) cannot be coerced by any superior power to engage in law-prescribed behaviour. This is due to the fact that there is no superior sovereign above them. Alternatively, the states cannot be regarded as sovereign, and the world state is essential.

22 J. Von Bernstorff, The Public International Law Theory of Hans Kelsen. Believing in Universal Law, New York 2010, 64.

23 Ibidem, 65. 
The middle position is that international law constitutes some other "sort of law" or a set of standards that is in no way complete or all-encompassing. ${ }^{24}$ The states are bound by these rules only because of the possibility of self-obligation. This implies, however, that their will can be reversed, and that they can always "unbind" themselves from the power of international law. Of course, this is unacceptable and theoretically fatally flawed from the perspective of Kelsen's pure theory of law. According to the Austrian lawyer, there can be no multiple conflicting groups of norms within the law (i.e. legal orders, each of which usurps its ultimate authority to regulate or to act on an exception) without an independent mediating rule of precedence that removes the collision. ${ }^{25}$ If one legal order cannot be declared subordinate to the other (because each claims sovereignty), then both must be subordinate yet to a third, higher system that grants them validity. All national legal orders need to derive their supreme authority from one and the same legal norm, which is the highest norm of the overarching superordinate system of international law. Also, the principle of the equality of sovereign legal orders must logically be a norm of the higher order from which all other state legal orders derive their validity. Kelsen's hypothetical basic norm or the Grundnorm is the only ultimate source which can grant to a legal order the quality of the highest power or authority, not dependent on any other power or authority. According to Kelsen, all other explanations are flawed, as they rely on a concept of power that is dependent on some other causal antecedent. ${ }^{26}$

These two central theses of the Kelsenian view of international law presuppose the normativity of international law. In other words, they require that international law be treated as a proper legal order. Only in this way may Kelsen's theory of the unity and totality of the legal

24 See H. Kelsen, Pure Theory of Law, Clark 2005, 329.

25 Ibidem, 332.

26 L. Vinx, Hans Kelsen's Pure Theory of Law. Legality and Legitimacy, Oxford 2007, 179. 
system be regarded as complete. According to Kelsen, the requirement that international law is law in a meaningful way is fulfilled only when the international legal community retains a monopoly over the use of force. In other words: "the forcible interference of a state in the sphere of interests of another state is, in principle, permitted only as a reaction against a delict". ${ }^{27}$

\section{THE ROLE OF THE BELLUM JUSTUM DOCTRINE IN KELSEN'S THEORY}

Within this general context of international law, Kelsen refers to the bellum justum doctrine. Typically for Kelsen, his logical and systematic way of thinking sets him at a starting point at which he observes two antithetical legal views on war under international law. According to one tradition of thinking - let it be described here as the realistic one - war is not explicitly forbidden by general international law. As long as a treaty renouncing war does not bind a state, it may freely resort to war in legal terms. All considerations of viewing war as a last resort or dressing it up as a reaction or sanction in response to hostilities undertaken by the other side is immaterial. The act of war is therefore not an international delict, or to put it in different terms - it is legally indifferent. Of course, the realistic argument cannot be upheld in modern international law, because the unlimited jus ad bellum as a competence on the part of individual states is explicitly excluded. Therefore, Kelsen rejects it. The second possible position rests on the opposite assumption that war is in principle forbidden under general international law. This legalist view, according to Kelsen, compels us to qualify war, as a fact of international life, as either a transgression of the legal norm prohibiting warring between states, which may amount to a delict of international law, or as a reaction to the violation of international law, which is a sanction in response to illegal war. Although Kelsen

27 H. Kelsen, General Theory of Law and State, New Brunswick - London 2006, 328. 
explicitly describes the legalistic view as the bellum justum theory ${ }^{28}$, it seems that he means for the just war doctrine to be the standard by which war as a sanction is distinguished from war constituting a delict. ${ }^{29}$

Like Paulus Vladimiri, Kelsen seems to find the essence of the bellum justum doctrine in the just cause (justa causa) principle by providing a historical insight into the development of the idea of just war. In his discussion, just cause essentially boils down to the view that ultimately there must be a certain kind of wrong suffered that warrants resort to a military action under international law. In Kelsen's approach, however, the most important presumption is that the just cause is formalised and restricted to a transgression of international law that constitutes an international delict. It follows that for the $\mathrm{Au}^{-}$ strian scholar, all reasons for the justification of war, or all transgressions of law that warrant resort to punitive war, must be legally codified. Through this reasoning, Hans Kelsen arrives at the point at which war - much the same as sovereignty - is simply absorbed and legalised by the all-encompassing legal system. It is important to add, in Kelsen's view, that this thesis stands independently of whether or not punitive wars as sanctions are actually waged (applied). Kelsen would therefore ignore accusations of hypocrisy addressed on the part of the Security Council or the Great Powers for sanctioning some States by the punitive use of armed force while turning a blind eye on others. For the pure positivistic approach of Kelsen's theory of law, the mere normative possibility of applying coercive means as sanctions is enough to support his thesis.

This view in fact brings Kelsen to the point that the use of the term "just war" is not entirely precise or may even be regarded as a misuse of words. "Just" usually denotes some kind of semantic link

28 H. Kelsen, Principles of International Law, New York 1967, 29.

29 J. Von Schmädel, Kelsen's Peace Through Law and Its Reception by the Contemporaries, Hitotsubashi Journal of Law and Politics 39(2011)1, 73. 
to justice or morality. Because the latter has no place in law according to Kelsen's pure positivist approach, it should be replaced with a term connoting legality that is at stake here. Therefore, what he effectively promotes could be more adequately named as a lawful war doctrine. In fact, in one of the footnotes to this discussion as it is developed in the book Principles of International Law he explicitly states in reference to the phrase "just war": "The term 'just' meaning 'legal' in the sense of positive international law". 30

Quite remarkably, in the end, Kelsen arrives at a similar point to the position of Paulus Vladimiri. His reasoning leads him through the necessity of choice between two logically possible options for the status of war under international law, and quite similarly to Vladimiri, he concludes by formulating the principle or presumption of the general illegality of war. The only notable difference is categorical. Kelsen limits the legitimate reasons for war to the question of consistency with positive legal rules. Vladimiri's exclusion of holy wars and his authorisation of wars in self-defence are essentially the same attempt to build a general legal standard, albeit understandably without regard to the separation of law, morals and theology. Both men struggle against the dominating contemporary mindsets of their eras - in the case of Vladimiri, the religious zeal of the late Middle Ages, and in the case of Kelsen - the 19th and early $20^{\text {th }}$ century positivist conviction of the duality of state and law, and the resulting unlimited sovereign power to wage wars.

\section{IS KELSEN A NATURALIST?}

The question arises of whether Kelsen's use of the term "just war" is only figurative. Why did this champion of a new formalistic method and the proponent of the objective science of law reach out for a notion so intimately related to the naturalistic tradition of thinking in

30 H. Kelsen, Principles of International Law, op. cit., 29, footnote 22. 
the philosophy of law, represented in particular by scholars such as Vladimiri? There may be several reasons for this move in Kelsen's theory.

First, undoubtedly, it is necessary to take into account Kelsen's own cosmopolitan political beliefs. In his analysis of the international legal order, Kelsen showed strong preferences for the monistic view, with the primacy of international law over the national legal order. According to some commentators, Kelsen even believed that the traditional meaning of the term had to be "radically suppressed" as an obstacle to the development of a unitary global legal system. ${ }^{31}$ Most importantly, Kelsen is explicit about the value of peace being the major aim of this order, which he makes explicit even in the very title of his 1944 book Peace through law. This again bears a striking resemblance to Vladimiri's pacifism. According to Kelsen, war is "a mass murder, the greatest disgrace of our culture", and therefore, peace must be our "foremost political task" ${ }^{32}$ Kelsen employs not only the notion of the bellum justum theory, but also another important cosmopolitan notion, the civitas maxima i.e. the idea of the world community of states, which he borrows from the 18th century legal thinker Christian von Wolff. ${ }^{33}$

Secondly, as mentioned earlier, Kelsen needs to secure the normativity of international law on the grounds of the pure theory of law. Because of his definition of the legal order, which rests on the essential coercive physical force in order to secure compliance, he is forced to show that international law, like national legal orders, is also capable of securing the monopoly of force and deploying it as a sanction, albeit in a decentralised fashion - through states or groups of states acting as organs of the international legal community.

31 D. Dyzenhaus, Kelsen, Heller and Schmitt: Paradigms of Sovereignty Thought, Theoretical Inquiries in Law 16(2015)2, 358.

32 H. Kelsen, Peace Through Law, Chapel Hill 1944, viii.

33 D. Zolo, Hans Kelsen: International Peace through International Law, European Journal of International Law 9(1998), 309. 
Therefore, a plausible argument is needed to reject the competing realist interpretation of international law and the views of the proponents of unlimited sovereignty. For him, recalling the bellum justum doctrine opens up a way for a certain sociological argumentation that is otherwise unacceptable by his own methodological rulebook: First, he uses the historical argument from tradition, and secondly, he develops the primitiveness thesis, which is strictly related to his theory of the evolution of legal systems.

The argument from tradition ${ }^{34}$ rests on a claim that since ancient times, wars were started by belligerents who pleaded some sort of a definite cause for war resorting to ideology, religion or morality. Secondly, it pertains to the views of authorities from Cicero, through St. Augustine and St. Thomas to Grotius, who all condemned wars waged without reason on philosophical and theological grounds. Paulus Vladimiri obviously also fits within that tradition. In order to tap into the argumentative power of the just cause element to support his primary thesis, Kelsen obviously finds it rhetorically useful to ground his argument in the just war theory narrative.

The argument from the primitiveness of the international legal order is far more complex and can be only summarised here in a cursory manner. Kelsen continues his historical-sociological inquiries by putting forward a claim that international law is a primitive legal order. ${ }^{35}$ The primary features of such a system are the extreme decentralisation of executive power in the community to the point of its delegation on a case-by-case basis to its individual members, as well as recourse to the technique of self-help in the application of sanctions. Such a primitive legal order may, however, evolve towards a more mature and centralised system represented by an ideal type of municipal legal order. In fact, this evolution has already started in the case of international law, and it leads from the development

$34 \mathrm{H}$. Kelsen, General Theory of Law and State, op. cit., 335-336.

35 Ibidem, 338-341. 
of compulsory jurisdiction to the centralisation of lawmaking and the executive powers. ${ }^{36}$ This naturalist thesis allows Kelsen to explain and justify the current obvious "technical" deficiencies of the international legal order, such as the lack of a proper authority (a compulsory world judicial system, for instance) to decide that a particular case of the use of force constitutes an international delict, and therefore, a punitive war as a sanction may be applied. In fact, Kelsen stresses this point greatly and is very enthusiastic about the possibility of the further development of an international judicial authority as an effective means towards enforcing - among other issues - his lawful war doctrine. Once again, on this point, he comes very close to Vladimiri's abovementioned idea of a judicial process as a way of deciding upon the legality or justness of wars based on adversarial proceedings over the facts or the law before an international body.

Thirdly, Kelsen may have believed that he never switched to naturalistic positions, because he never compromised his methodological assumptions of the pure theory. He does not embrace any naturalistic core thesis: He does not accept that there are any universal extra-legal criteria for the validation of the positive general international law on war, nor does he claim that such criteria, even if they existed, could be grounded in nature. ${ }^{37} \mathrm{He}$ treats bellum justum as an intra-legal concept, which is also characteristic of his approach towards sovereignty. ${ }^{38}$ However, he comes close when he directly accepts the natural-legal explanation of the equality of states or describes ethics as the ground that nourishes the growth of international law and conditions its development. ${ }^{39}$ In the end, however, one has to remember that Kelsen's theory envisages law as a complete and universal system that absorbs other normative considerations such as morality or religion.

36 H. Kelsen, Peace Through Law, op. cit., passim.

37 Cf. J. Zajadło, Prawo natury, w: Leksykon współczesnej teorii i filozofii prawa. 100 podstawowych pojęć, red. J. Zajadło, Warszawa 2007, 268.

38 See J. Von Bernstorff, op. cit., 73-77.

39 D. Zolo, op. cit., 312. 
As long as no methodological breach is made, Kelsen's doctrine remains intact as a pure normativist approach, and all ethical links to the moral underpinnings of the just war tradition remain merely political considerations. ${ }^{40}$

\section{RELEVANCE OF KELSEN'S CONCEPT OF LAWFUL WAR}

Several lines of critique are possible and have been formulated towards Kelsen's concept of the just war theory. It was already mentioned that his formulation of the bellum justum doctrine might be regarded as oversimplified, serving merely an instrumental purpose in the discussion on the validity of international law. Therefore, for some scholars, the Kelsenian notion of just war is irrelevant, as it did not retain any of the ethical meaning that underpinned the earlier tradition, as exemplified by Paulus Vladimiri and other scholars. Some believe that Kelsen simply blurred the distinction between international law and morality. ${ }^{41}$ These criticisms have already been addressed to a certain degree above. What remains important, however, is the possibility of the contemporary relevance of Kelsen's approach.

The most important problem with Kelsen's attempt to transform just war theory into lawful war doctrine lies in the theoretical capacity of the notions of a delict and a legal sanction. In Kelsen's pure theory, a delict is "the behaviour of the individual against whom the sanction, as a consequence of this behaviour, is directed". ${ }^{42}$ The sanction not only has a punitive or restorative purpose, but also a preventive one, which is perhaps the dimension that Kelsen wishes to underline. By attaching a sanction to a norm, the lawmaker aims at preven-

40 Cf. A. Jakab, Kelsen's Doctrine of International Law: Between Epistemology and Politics, Austrian Review of International and European Law 9(2004), 49-62, http://dx.doi. org/10.2139/ssrn.1918404, 13.02.2016.

41 R. Campione, Development of 'Just War' Theory, in: Humanitarian Interventions, ed. J. Zajadło, S. Sykuna, T. Widłak, Gdańsk 2010, 50-51.

42 H. Kelsen, General Theory of Law and State, op. cit., 54. 
ting certain behaviour considered detrimental to society. However, a delict, including an international one, is also described repeatedly in Kelsen's writings as a condition for sanction. In other words, the application of a coercive act is conditioned by the prior transgression of a legal norm. In international law, according to Kelsen, the sanctions of reprisals and war are not a punishment or a civil execution, but a forceful depravation of values. ${ }^{43}$ In any case, it follows that the application of a sanction cannot be a prospective act, which is prior to the transgression. The preventive character of a sanction that is derived from its existence or its validity is separate from its actual application, which may happen only after the prohibited behaviour has taken place. This does make Kelsen's concept of lawful (just) war very useful for the purposes of the discussion of one of the most important and controversial developments in modern war theory: pre-emptive and preventive wars.

\section{CONCLUSION}

On the whole, Hans Kelsen's use of the theory of just war currently remains illustrative of some general processes. First, it shows that the just war tradition is inextricably linked with its ethico-theological underpinning. Kelsen's modern attempt to replace moral judgement with "juristic judgement" remains unconvincing, if only for the fact of the elusive nature of postmodern globalised international ethics. Kelsen himself is much at pains when he tries to support the cosmopolitan agenda with pure logical methodology. Secondly, just war, as an important ethical tradition, proves to be thoroughly resistant to projects aimed at its absorption by positive law and total juridisation. The largely failed attempt by one of the leading positivist thinkers of the 20th century may be a weighty argument to support this thesis. Yet, on the other hand, the adoption of just war theory

43 H. Kelsen, Pure Theory of Law, op. cit., 110. 
after a century of abandonment by Hans Kelsen, albeit in a limited and instrumental way, may indicate its unfailing appeal as a source of theoretical inspiration in legal and philosophical thinking. In this sense, the comparative study of the views of such distant figures as Paulus Vladimiri and Hans Kelsen demonstrates a certain remarkable universality of this tradition, as well as its resilience in the face of methodological and political assumptions. In the cases of both scholars, it has also proved capable of serving as a viable vehicle for arguing for politically subversive views against the mainstream thinking of their ages.

\section{BIBLIOGRAPHY}

Armstrong D., Farell T., Lambert H., International Law and International Relations, Cambridge University Press, New York 2007.

Bierzanek R., Symonides J., Prawo międzynarodowe publiczne, LexisNexis, $7^{\text {th }}$ ed., Warszawa 2003.

Kelsen H., Czysta teoria prawa, ed. A. Bosiacki, trans. R. Szubert, LexisNexis, Warszawa 2014.

Campione R., Development of 'Just War' Theory, in: Humanitarian Interventions, ed. J. Zajadło, S. Sykuna, T. Widłak, Wydawnictwo Uniwersytetu Gdańskiego, Gdańsk 2010.

Dyzenhaus D., Kelsen, Heller and Schmitt: Paradigms of Sovereignty Thought, Theoretical Inquiries in Law 16(2015)2, 337-366.

Ehrlich L., Pisma wybrane Pawta Wtodkowica, vol. I, Instytut Wydawniczy „Pax”, Warszawa 1968.

Górski K., Z dziejów walki o pokój i sprawiedliwość międzynarodowq-ostatnie stowo Pawta Wtodkowica o Zakonie Krzyżackim, PWN, Toruń 1964.

Jakab A., Kelsen's Doctrine of International Law: Between Epistemology and Politics, Austrian Review of International and European Law (2004), 49-62, http:// dx.doi.org/10.2139/ssrn.1918404.

Jasudowicz T., Śladami Ludwika Ehrlicha: do Pawta Wtodkowica po naukę o prawach cztowieka, I-III, Wydawnictwo Comer, Torun 1995.

Kelsen H., General Theory of Law and State, Transaction Publishers, New Brunswick - London 2006. 
Kelsen H., Peace Through Law, The University of North Carolina Press, Chapel Hill 1944.

Kelsen H., Principles of International Law, Holt, Rinehart and Winston, New York 1967.

Kelsen H., Pure Theory of Law, The Lawbook Exchange, Clark 2005.

Kelsen H., The Legal Process and International Order, The New Commonwealth Research Bureau Publications, series A, no. 1, London 1934.

Vinx L., Hans Kelsen's Pure Theory of Law. Legality and Legitimacy, Oxford University Press, Oxford 2007.

Von Bernstorff J., The Public International Law Theory of Hans Kelsen. Believing in Universal Law, Cambridge University Press, New York 2010.

Von Schmädel J., Kelsen's Peace Through Law and Its Reception by the Contemporaries, Hitotsubashi Journal of Law and Politics 39(2011), 71-83.

Wesołowska E.A., Pawet Wtodkowic - wspótczesne znaczenie pogladów i dokonań, Wydawnictwo Adam Marszałek, Płock 2001.

Zajadło J., Prawo natury, in: Leksykon wspótczesnej teorii i flozofii prawa. 100 podstawowych pojęc, ed. J. Zajadło, C.H. Beck, Warszawa 2007.

Zolo D., Hans Kelsen: International Peace through International Law, European Journal of International Law 9(1998), 306-324.

This article is part of a research project financed by the National Science Centre, Poland (2016/23/D/ HS5/02613).

Tomasz Widłak

tomasz.widlak@prawo.ug.edu.pl

University of Gdańsk, Faculty of Law and Administration, Department of Theory and Philosophy of Law and State

Jana Bażyńskiego 6, 80-309 Gdańsk, Poland

DOI: 10.21697/spch.2017.53.3.04 